\title{
Leadership Positions of Economic Relations between Ukraine and China
}

\author{
Tetiana Shestakovska1 $^{1}$ (), Ievgeniia Markova2 ${ }^{2}$ (), Nadiia Lebiedieva ${ }^{3 *}$ \\ ${ }^{1}$ Chernihiv University National of Technological, Chernihiv, Ukraine \\ ${ }^{2}$ Kherson Marine College of the Fisheries Industry, Kherson, Ukraine \\ ${ }^{3}$ Kherson State Agrarian and Economic University, Kherson, Ukraine \\ Email: shestakovska27@gmail.com,mmmmama72@gmail.com, *vsesvit894@ukr.net
}

How to cite this paper: Shestakovska, T., Markova, I., \& Lebiedieva, N. (2021). Leadership Positions of Economic Relations between Ukraine and China. Modern Economy, 12, 775-786.

https://doi.org/10.4236/me.2021.124038

Received: March 8, 2021

Accepted: April 17, 2021

Published: April 20, 2021

Copyright $\odot 2021$ by author(s) and Scientific Research Publishing Inc. This work is licensed under the Creative Commons Attribution International License (CC BY 4.0).

http://creativecommons.org/licenses/by/4.0/

\begin{abstract}
In the context of the rapid development and growth of the Chinese economy, the implementation of the project of the new economic pole of the world is of current importance. China is a strategic partner for Ukraine that can significantly influence the development of the domestic economy. The purpose of the article is to study the main trends and the prospects for the development of cooperation between Ukraine and China in the context of determining positive effects and possible risks for the domestic economy. The article examines the current state of economic cooperation between Ukraine and China. The area of interests of China in Ukraine has been outlined, namely the possibility of attracting Ukrainian technologies to the Chinese market with the location of production on the territory of China. It has been established that it is a significant threat for Ukraine, because the Chinese partners will master Ukrainian technologies in a few years and the need for Ukrainian partners will disappear.
\end{abstract}

\section{Keywords}

Economy, Relations, Cooperation, Strategic Partnership, Development

\section{Introduction}

The People's Republic of China (hereinafter referred to as the PRC) is very promising for the Ukrainian business since it has proved itself as an authoritative state with a powerful economy. It is worth noting that the PRC takes second place in terms of the volume of trade between Ukraine and other countries of the world. Ukraine and the PRC have already cooperated by some areas, such as machine building, transport services and others. However, Ukraine is more in- 
teresting for the PRC as a supplier of raw materials, and the market for the sale of its goods, and it is not suitable for Ukraine in the long term. On the other hand, support for stable and predictable economic relations with the PRC is an important element for Ukraine to support national economic security. Mutually beneficial trade and economic relations are the keys to form an attractive field for deepening bilateral investment, innovation, scientific and technical, and educational cooperation. It should be noted that the Chinese authorities have proclaimed the One Belt One Road Initiative. Indeed, the Great Silk Road, which united China and Europe at the beginning of our era, may again appear on the map of the world. To revive the legend, China has offered the world community an unprecedented by the scale and ambitiousness initiative, which unites more than 60 states with a population of almost 4.4 billion people and the total GDP of $29 \%$ of the world. This is not just a project. It is a peculiar global "economic platform" for the further development of countries on the Eurasian continent (Povorzniak \& Perebyinis, 2015). China has a fairly large stock of investment that Ukraine needs. In turn, Ukraine is attractive for China in the field of technology and agriculture. However, close cooperation can have not only positive but also negative consequences for the Ukrainian economy. There are some threats that can arise as a result of economic cooperation between Ukraine and China for our country; therefore, it is worth considering the significant difference in the economic power of the states. The key risk is use of domestic technologies for creation of Chinese samples that have a much greater financial resource for mass production. In addition, Beijing has significantly greater sales opportunities, taking into account its position in the markets of Africa, South America and Southeast Asia.

Relations between Ukraine and China have been studied by economists in a comprehensive way. The issue on a strategic partnership and economic-trade relations in general as part of the foreign economic relations of Ukraine with the PRC is especially relevant at the present stage of development of the domestic economy. In particular, they have been studied by the following scientists: Yu. Lupenko (Lupenko, 2015), V. Povorzniak, V. Perebyinis (Povorzniak \& Perebyinis, 2015), M. Smykova (Smykova, 2006), P. Kaminsky, (Kaminsky,, 2014), Chernyk, H. Batyshcheva (Chernik \& Batyshcheva, 2010), Kh. Menh (Menh, 2005), Ye. Medvedkina (Medvedkina, 2011), S. Sidenko (Sidenko, 2016; Sidenko \& Nevgad 2016), V. Yermachenko (Yermachenko, 2015), N. Micholska (Micholska, 2016) and others.

At the present stage of globalization, the most widespread form of international economic relations is bilateral cooperation. M. Malskyi, M. Matsiakh, R. Enverov define it as the state contacts between the two countries in the political, economic, cultural, and informational areas. Special and permanent missions are formed, and agreements and treaties are concluded for interaction (Malskyi \& Matsiakh, 2007).

R. Enverov notes that in the current conditions, bilateral relations between the countries can also have a mixed character, which simultaneously maintains 
economic interaction, and, at the same time, there is a political confrontation that can be transformed to open conflict. Such a format of relations is due to the interest of large economies to consolidate leadership positions and to increase the impact on relatively small economies in the system of their own geopolitical interests. A relatively new form of bilateral relations is interdependence that arises between the two countries as a result of long-term interaction at different levels, which makes these partners more vulnerable to external challenges because the crisis phenomena affecting one of the partners automatically extend to another one (Enverov, 2014).

A. Mokii, R. Enverov, L. Yaremko, M. Fleichuk distinguish the following criteria approaches to the definition of stable partnership between countries: presence of common geostrategic interests and goals; presence and severity of contradictions in relations; historical experience of achieving compromises in resolving contradictions; complementarity of the structure of the national, including the economic systems of the partner countries; unity of civilization factors of strategic partnership (Mokii, 2006).

Foreign economic development strategies of the PRC are formed mainly on the basis of their own Chinese School of International Relations, which, according to Chinese scientists, is an alternative to American, English, French and other schools.

Despite the achievements of many scientists, the issue of strategic cooperation between Ukraine and the PRC requires further research. As the One Belt One Road Initiative continues, there is a need to analyze and control dominant factors, negative trends, impact on the country's economic security, problems of expansion and further transformation of trade relations.

\section{Materials and Methods of Research}

In the course of research, general scientific and special methods of research have been used, in particular: theoretical generalization, comparison and morphological analysis-in the process of formation of the conceptual-categorical apparatus of research; system analysis-for study the theoretical foundations of international economic relations; economic-mathematical analysis-for study of foreign trade activity of Ukraine and the PRC; SWOT-analysis of problems and prospects for the development of economic relations between Ukraine and China; evaluation of complementarily of bilateral trade, relations of comparative advantages, intensity, intra-industry trade.

\section{Results and Discussions}

In the modern world, no country can stand aside from radical transformations in the world economy, and this is confirmed by globalization processes and innovative transformations in the economy. At the same time, the main tendencies in economic development show that national economies tend to the openness, which causes an intensification of the competitive struggle of commodity producers in world markets and the division of all countries into the leading countries that form the core, the centre of the world economy, and the coun- 
tries-followers that make up it peripherals. Consequently, in many countries, the role of the state in the sphere of management of the national economy is decreasing; governments are faced with the problem of finding new forms and methods for adapting the national, economic and political-legal environment to the modern requirements for the implementation of international economic relations. A successful example of avoiding such phenomena is the PRC, which is building its own innovation system, which combines global experience in innovation and technology transfer with the successful and rapid adaptation of technologies to the national economy. At the same time, the basis of the PRC's economic strategies is not only the development of a national but also a supranational sphere of production and transfer of knowledge and technologies.

We believe that bilateral trade between Ukraine and the PRC in case of effective foreign economic policy and rational use of the resource potential of bilateral cooperation has great prospects. Table 1 confirms our point of view. The share of the PRC in the geographical structure of foreign trade turnover during 2017 is an average of $8.9 \%$ (2.3\% of total exports and 3.3\% of total imports).

Due to increasing the attractiveness of the rapidly expanding domestic market, the PRC was able to obtain technology on an unprecedented scale, which has led to the creation of research centres. At the same time, due to favourable market conditions, the PRC succeeded in uniting different foreign investors and achieving multilateral exchange of technologies. Chinese car manufacturers have signed joint venture agreements with foreign competing companies. This situation allowed the Chinese partner to take best practice from both competitors and to be the only player among the three participants which has access to the other two. Another interesting feature is that Chinese companies began to own a share of stock of foreign investment of leading technology companies, thus opening up another channel to access technology. It should be noted that cooperation on the basis of attraction of license technologies is also a strategically thought-out step: firstly, during the transfer of licenses, there is interaction with foreign companies, which account for the largest number of innovations; secondly, their own improvements are made on the basis of these technologies. The continuous growth of the country's scientific potential is evidenced by the unceasing development of one of the most important forms of scientific and technological exchange which is the creation of research centres in conjunction with foreign companies.

As a result of the technology transfer through the scientific and technical centres, in 2012, expenditures on R\&D in the PRC amounted to 1.7\% of GDP which is 143 billion USD; by this indicator, the PRC took 21st place in the world. At the same time, Ukraine spent $0.86 \%$ of GDP on R\&D, which is only 1.51 billion USD; by this indicator, Ukraine took 36th place (The World Bank, 2019).

As can be seen from Table 2, during 2009-2018, the saturation of the Chinese economy with the best technologies was taking place, domestic expenditures on R\&D were growing, on average, by $15 \%-20 \%$ per year. For developed countries, products were produced under license, and for third world countries, as licensed, and like its analogues, which copied prototypes. 
Table 1. Indicators of foreign trade between Ukraine and the PRC for 2008-2017.

\begin{tabular}{ccccc}
\hline Year & $\begin{array}{c}\text { Exports from Ukraine } \\
\text { to the PRC, billion USA }\end{array}$ & $\begin{array}{c}\text { Imports from Ukraine } \\
\text { to the PRC, billion USA }\end{array}$ & $\begin{array}{c}\text { Trade Balance, } \\
\text { billion USA }\end{array}$ & $\begin{array}{c}\text { Share of the PRC } \\
\text { in foreign trade }\end{array}$ \\
\hline 2008 & 0.55 & 5.6 & -5.05 & $6 \%$ \\
2009 & 1.43 & 2.73 & -1.3 & $6 \%$ \\
2010 & 1.32 & 4.7 & -3.38 & $5.80 \%$ \\
2011 & 2.18 & 6.27 & -4.09 & $6.10 \%$ \\
2012 & 1.78 & 7.9 & -6.12 & $6.30 \%$ \\
2013 & 2.73 & 7.903 & -5.18 & $7.50 \%$ \\
2014 & 2.67 & 5.41 & -2.73 & $7.40 \%$ \\
2015 & 2.4 & 3.77 & -1.37 & $8.10 \%$ \\
2016 & 2.3 & 3.5 & -1.5 & $8.70 \%$ \\
2017 & 2.3 & 3.3 & -1.4 & $8.90 \%$ \\
\hline
\end{tabular}

Source: (the State Statistics Service of Ukraine).

Table 2. Gross domestic expenditures on R\&D in the PRC, billion CNY.

\begin{tabular}{ccccccccccc}
\hline Year & 2009 & 2010 & 2011 & 2012 & 2013 & 2014 & 2015 & 2016 & 2017 & 2018 \\
\hline Expenditures & 580.2 & 706.3 & 868.7 & 1029.8 & 1184.7 & 1301.6 & 1425.2 & 1553.5 & 1677.7 & 1811.9
\end{tabular}

It should be noted that the relations between Ukraine and China began in 1992 and rapidly developed until 2004. To a large extent, this was due to a high level of political dialogue, creation of the necessary legal framework and practical implementation of the agreements reached in various spheres of cooperation (trade and economic, military-technical, scientific-educational, and cultural).

During the visit, the Chinese leader expressed four theses, which, in his opinion, would allow the two countries to use the "chance, advantages and potential possibilities" for cooperation (Sidenko, 2016; Sidenko \& Nevgad, 2016):

1) Increase in the volume of trade, optimization of the trading structure, increase in the share of high value-added products and high technology products in trade and economic cooperation,

2) Realization of major collaborative projects. Governments must create the conditions for this so that these projects bring social and economic benefits as quickly as possible.

3) Expansion of mutual investment. The Chinese government will encourage Chinese enterprises to invest in Ukraine and support financially important cooperation projects.

4) Deepening cooperation in the field of high technologies, using the principle of complementarity. Cooperation in such areas as aviation, shipbuilding, bioengineering, development of new materials. Collaboration on the implementation and application of scientific and technological developments in industrial production.

Since 2000, there has been a positive trend in the development of economic 
relations between the two states, which has especially intensified, in direct foreign investment from the PRC to Ukraine since 2007 (Figure 1). The dynamics of Chinese direct investment in Ukraine's economy had a positive upward trend (\$28.3 million in 2018 and $\$ 10$ million in 2007).

The dynamics of export-import operations and directions of the development of cooperation for the last 6 years make it possible to conclude that an increase in trade turnover will occur due to the growth of imports of Chinese goods and services into Ukraine. At the same time, domestic exports to the PRC will continue to have a leap-shaped nature and are unlikely to exceed the monthly figure of \$200 million USD.

According to the statistical data of Ukraine, for 9 months of 2018, the turnover amounted to 6.67 billion USD and increased by $22.5 \%$; exports of goods from Ukraine to China amounted to 1.4 billion USD and decreased by $0.9 \%$; imports of Chinese goods to Ukraine amounted to 5.23 billion USD and increased by $29.9 \%$. The negative balance for this period amounted to 3.79 billion USD.

Imbalance is also observed in the priority directions of bilateral cooperation. Thus, while Beijing aims at cooperation in order to gain access to technologies and resources, the Ukrainian side is only interested in China's financial resources due to growing imports of Chinese goods to the country.

One of the main disadvantages of cooperation between Ukraine and China is the lack of strategic directions for the use and borrowing of Chinese technologies and innovations, which could be an impetus for improving existing technologies in Ukraine and attracting foreign experience. Another disadvantage is that the Ukrainian side gives China the opportunity to use domestic technology to locate production in its territory that provides jobs in the Chinese, but not the Ukrainian economy.

Presenting the concept of the Chinese initiative, Xi Jinping focuses on the following key tasks that will be performed: strengthening the coordination of the participating states in the political sphere; activation of the development of a single infrastructure network; harmonization of trade regimes, unification of trade procedures; growth of currency circulation, in particular due to the expansion of the use of national currencies of the participating states; strengthening of the role of "economic diplomacy", growth in tourist flows, expansion of cultural interaction (Honcharuk 2016). In our opinion, the PRC de facto initiated the creation of a new global economic platform aimed at further integration of states into a single economic space. Now the initiative is called the One Belt One Road.

From an economic point of view, the One Belt One Road Initiative focuses on the creation of new and modernization of existing economic corridors-transport communications (roads, railways, airports, maritime terminals, etc.), as well as related infrastructure (including logistics centres, warehouses terminals, etc.). The result of this integration should be, in particular, complete removal of barriers that hinder free movement of economic factors (goods, services, capital, labour, currency, etc.). 


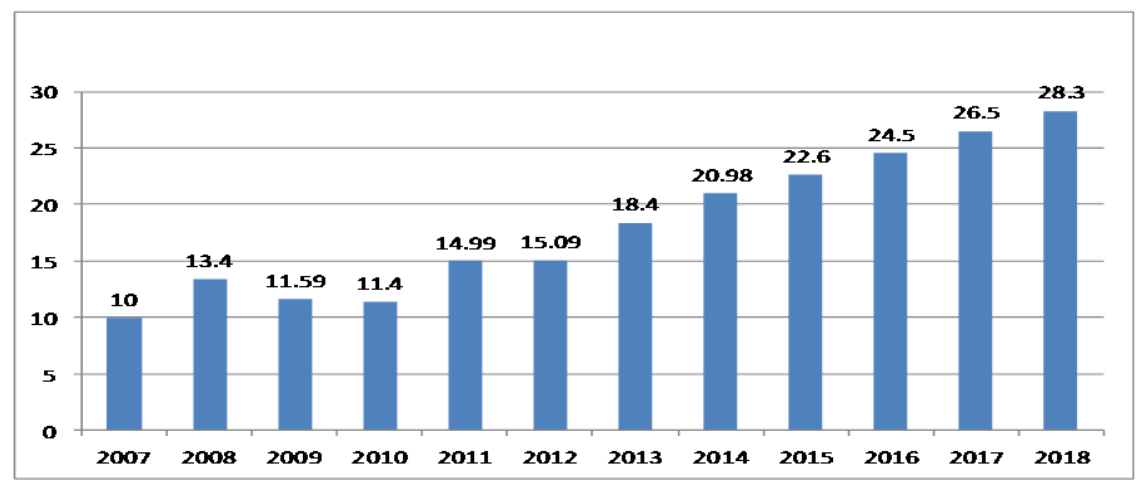

Figure 1. Dynamics of direct investment from the PRC to the economy of Ukraine, million USD.

In its current form, the One Belt One Road Concept looks like one of the most attractive geo-economic projects for Ukraine. Currently, its key advantages are inclusiveness, openness, and efficiency for all participants, transition to unified rules of trade, as well as integration and coordination of programs and development strategies of countries. The Chinese project does not contradict Ukraine's aspiration for further economic cooperation and economic integration with the $\mathrm{EU}$, and on the contrary, it can strengthen the advantages of Ukraine in this process, provide incentives for economic development in general. This project can also provide an alternative and reduce negative consequences of the severance of economic relations with the Russian Federation and deal with Russia's ban on transit of Ukrainian goods to Asia.

The draft the New Silk Road is definitely needed for Ukraine, since it is beneficial, first of all, in terms of taking advantages of a transit country in the context of integration into large-scale and perspective interregional cooperation of an innovative type. Furthermore, it is necessary for solving fundamental economic problems, which demand too much technological and financial resource, and the prospect of their appearance in the next $10-20$ years is rather uncertain. Ukraine's participation in the creation of the infrastructure of the economic zone of the New Silk Road would greatly contribute to the progress in raising the level of employment of the able-bodied population in those regions through which the New Silk Road would pass. It should be noted that Ukraine and China continue to explore potential opportunities for Ukraine to participate in the One Belt One Road Project, however, it is evident that Ukraine has focused on transport and logistics projects, although the potential of the One Belt One Road Project is significantly wider.

To sum up, it should be noted that today a large number of documents on further cooperation between Ukraine and China have been developed. At the same time, practice and effectiveness of the implementation of all prepared and agreed documents are extremely low. The SWOT-analysis of the current state of trade relations between Ukraine and China has been conducted, the result of which is presented in Table 3 . 
Table 3. SWOT analysis of the current state of trade relations between Ukraine and China.

\begin{tabular}{|c|c|}
\hline Strengths & Weaknesses \\
\hline Scientific and technical potential and existing cooperation in this field & Legislation of Ukraine \\
\hline Highly qualified staff & Fulfillment of laws of Ukraine in the field of foreign investment and \\
\hline Cooperation in mechanical engineering and transport services & protection of the rights of private property and rights to it \\
\hline Conditions creation for the development of innovations & Low population solvency \\
\hline Functioning of a sufficient number of scientific institutions & Unstable economic situation \\
\hline Availability of a suitable base for research and development of & Lack of well-established trade and economic policy \\
\hline new technologies and equipment & Lack of favourable investment climate \\
\hline Ecology & Unregulated conditions for simplifying trade procedures with the PRC \\
\hline Culture & Ukraine is perceived as a supplier of raw materials \\
\hline Opportunities & Threats \\
\hline Possibility for Ukraine to become a transit country & Possible change in investment purposiveness \\
\hline Attracting direct investment & Negative balance of foreign trade with the PRC \\
\hline Expanding mutual Investment & Outstanding growth rates of Chinese imports \\
\hline Activation of trade and economic cooperation & Non-rational changes in the commodity structure of foreign trade \\
\hline Deepening cooperation in high technology & Excessively high share of high-tech products in imports \\
\hline Technology development & Narrow nomenclature and raw material nature of Ukraine's exports \\
\hline Creation of new and modernization of existing transport communications & Soil depletion in Ukraine \\
\hline Removing barriers & Degeneration of Ukrainian agricultural products \\
\hline Restoration of Ukraine's position in world technology markets & Illegal labour migration \\
\hline Realization of large projects & Use of Ukrainian technologies for creation of Chinese samples \\
\hline \multicolumn{2}{|l|}{ New products } \\
\hline \multicolumn{2}{|l|}{ Delivery terms reduction } \\
\hline \multicolumn{2}{|l|}{ Ability to build infrastructure } \\
\hline Growth of tourist flows & \\
\hline Expansion of cultural interaction & \\
\hline
\end{tabular}

There are some threats that can arise as a result of economic cooperation between Ukraine and China for our country; therefore, it is worth considering the significant difference in the economic power of the states. The key risk is use of domestic technologies for creation of Chinese samples that have a much greater financial resource for mass production. In addition, Beijing has significantly greater sales opportunities, taking into account its position in the markets of Africa, South America and Southeast Asia.

However, in our view, perspective directions of mutually beneficial cooperation between Ukraine and China can be attributed, first of all, to cooperation in the scientific and technical sphere. Continued cooperation in this sphere will allow domestic scientists to participate in the latest developments in all spheres, in particular, in the production of space and aviation products; marine high-tech vessels; high-tech railway transport equipment; energy saving and vehicles using new types of energy; new materials; high-tech medical devices, etc.

Based on the scientific and technical cooperation, priority projects in the development of bilateral relations between Ukraine and the PRC should be primarily aimed at high value-added products, in particular: space and aviation prod- 
ucts; shipbuilding; engineering products (including the construction of marine high-tech vessels and railroads); energy saving and vehicles with alternative energy sources; development of new materials; bioengineering; high-tech medical devices; military products.

An important direction for Ukraine is also the expansion of infrastructure projects (construction of roads, seaports, logistic hubs, airports, etc.).

There are also prospects for attracting Chinese investors to modernize the housing and communal infrastructure of the country, individual industrial enterprises, etc. At the same time, when deepening bilateral relations in these areas, Ukraine should take into account the experience of other countries that have close cooperation with the PRC. And this experience is not always positive.

It is also worth taking into account the threats as a result of such cooperation between Ukraine and China. Indeed, depending on the peculiarities of the agro-industrial complex in different states, national legal bases and economic risks, China uses different methods of investing capital to the agro-industrial complex: purchase of land (Australia, France), lease (Brazil, Argentina, Russia), provision with agricultural machinery and workers in exchange for part of the crop (Venezuela, Zimbabwe). In the framework of this program, China is extremely interested in investing its capital in the Ukrainian market.

Given these problems and for intensification of scientific and technical cooperation and successful cooperation between Ukraine and the PRC, in general, there are several conditions required from the side of the Ukrainian government:

1) Fulfillment of laws of Ukraine in the field of foreign investment and protection of the rights of private property and rights to it. The elimination of controversial court decisions, full support of a foreign investor in the legal field of Ukraine-all of this will protect foreign investment from raider seizures and legal tyranny.

2) Assessment of the investment climate in the country. Constant monitoring of macroeconomic indicators and their dynamics should point to problems in different spheres of economy, and therefore on the overall investment attractiveness.

3) Reduction of the tax burden on all areas of doing business. Maximally possible reduction of tax rates; reduction of the total amount of taxes; reduction and also in some cases complete refusal of tax inspections and control. All these measures will make the Ukrainian economy as attractive as possible to investors because investing in the Ukrainian economy will be beneficial. Thus, in 2015, the general rate of tax on commercial profits in the PRC was $67.8 \%$, in Ukraine- $52.2 \%$. As you can see, the difference in rates between the two countries is not big. At the same time, for example, in the OAU, this rate is $15.9 \%$, in the UK- $32 \%$ (Political Relations between Ukraine and China).

4) Improvement of the effectiveness of the actions of governmental ministries to prevent national economic crises and risks in world markets. In the long run, it is difficult to guarantee stable and sustainable economic development due to insufficient domestic demand, weak economic bases, irrational export structure, 
imperfect banking system. The Ukrainian market is still immature. There are high risks for investment and cooperation. Ukraine is rich in natural resources, has a strong industrial base and has great scientific and technical potential. Therefore, lack of short-term and long-term prospects for financial and political shocks in the economy of the country should change both the international rating of the country from different agencies and, accordingly, the attractiveness of the country for foreign investors.

\section{Conclusion}

Analyzing the current state of the Ukrainian economy, it remains indisputable that for a successful economic development, we need a strong partner, which will ensure the inflow of foreign investment. The most potential partner for today is China. The PRC has a great investment, financial, and scientific potential. Currently, the amount of investments in Ukraine is insignificant. They have a low technical level. When investing, Chinese investors need to comply with Ukrainian laws, assess the investment situation, raise awareness of risk prevention, and, when drawing up an investment plan, take into account the peculiarities of the Ukrainian market. The criteria for non-compliance in relations between Ukraine and the PRC are the lack of civilizational unity, the language barrier, differences in the principles of building society, as well as the considerable distance of countries.

Therefore, an extremely important task for the economic bloc of the Ukrainian government is the introduction of effective instruments for stimulating economic activity, conducting a sound trade and economic policy, and creating a favourable business climate for foreign partners. In particular, it is appropriate for the Ministry of Economic Development and Trade of Ukraine to prepare proposals for the enhancement of bilateral trade, economic and investment relations. Even under tight budget constraints, it is expedient and possible to take measures that do not require additional financing from the budget, including support for participation of enterprises in exhibitions and fairs; interaction of cross-border electronic business platforms; improvement of the regulatory environment for trade between the two countries, and creation of conditions for the facilitation of trade procedures; creation of joint ventures in the industrial sector on the basis of existing industries, in particular, in the field of transport machine building, aircraft building and power engineering.

The analysis of trade between Ukraine and the PRC proves that the current tendency increases the threat of the transformation of Ukraine into a raw material base not only for developed countries, but also for China, and to the market of Chinese goods. It is expedient to review the structure of exports as soon as possible, reduce the export of raw materials and cheap materials, and implement state measures to stimulate the increase of sales of finished and upgraded products. However, despite the undeniable benefits of strengthening and deepening economic cooperation with China, there are serious potential threats to our 
country that can cause significant structural changes in 10 - 15 years. In this regard, while intensifying economic cooperation with China, it is necessary to build a strategic map of cooperation with the aim of protecting the country from negative externalities related to the peculiarities of doing business with Chinese partners.

\section{Conflicts of Interest}

The authors declare no conflicts of interest regarding the publication of this paper.

\section{References}

Chernik, P., \& Batishcheva, G. (2010). Ukraine-China: State and Prospects of Relations. State and Law, 1, 14-18.

Enverov, R. R. (2014). Development of Economic Relations between Ukraine and Turkey in the Process of Regional Integration (238 p). Candidate of Economic Sciences: 08.00.02, Lviv: National Institute for Strategic Studies.

Honcharuk, A. (2016). The Silk Road: From Concept to Practical Steps (the Interaction Format 16+1). Strategic Panorama, No. 1,26-36.

Kaminsky, P. D. (2014). Analysis of Approaches to the Development of Large Industrial Complexes in Ukraine in the Context of Neo-Industrialization. Global and National Economic Problems, 2, 532-537.

Lupenko, Y. (2015). Current State and Prospects of International Integration of the Agricultural Sector of Ukraine: Tasks of Agroeconomic Science. Economics of Agro-Industrial Complex, 6, 6-10.

Malskyi, M. Z., \& Matsiakh, M. M. (2007) Theory of International Relations: Textbook (3rd ed., 461 p). Kyiv: Zhannia.

Medvedkina, Y. O. (2011). Taxonomy of Uncertainty of World Economy Trends in the Context of Ensuring Financial Stability of National Economies. In Rozumkov, Problems and Prospects for the Development of Cooperation between the Countries of Southeast Europe within the BSEC and GUAM (pp. 469-474). Kyiv: Zhannia.

Menh, K. (2005). Ukrainian-Chinese Relations at the End of the 20th-Beginning of the 21th Centuries. Ph.D. Thesis, Kyiv: History, Taras Shevchenko National University of Kyiv.

Mokii, A. (2006). The People's Republic of China as a Strategic Partner of Ukraine in the Context of Accelerating the Process of European Integration (52 p). Lviv: Regional Branch of NISS, Lviv Commercial Academy, NGO "Institute for International Economic Research".

Povorzniak, V., \& Perebyinis, V. (2015). The One Belt One Road (OBOR) Project: Opportunities for Ukraine (31 p). Kyiv: International Carnivorous Plant Society.

Sidenko S.V. (2016). International Cooperation of Ukraine in the Field of Innovations. The Strategy of Development of Ukraine, 1, 172-176.

Sidenko, S.V., \& Nevgad, A. (2016). Ukraine's International Cooperation in the Field of Innovation. Development Strategy of Ukraine, No. 1, 172-176.

Smykova, M. R. (2006). Tourism: Economics, Management and Marketing. Almaty: Nur-Press.

Micholska, N. (2016). The Ministry of Economic Development and Trade of Ukraine. 
Trade and Economic Cooperation with China Is One of the Priorities for Ukraine Today.

http://me.gov.ua/News/Detail?lang=uk-UA\&id=afa2e521-ee22-45c6-8802da0e9122463 $\underline{\text { 2\&title=NataliiaMikolska-TorgovoekonomichneSpivrobitnitstvoZKitamOdinZPrioritet }}$ ivDliaUkrainiSogodni

The State Statistics Service of Ukraine. http://www.ukrstat.gov.ua

The World Bank (2019). Total Tax and Contribution Rate (\% of Profit). http://data.worldbank.org/indicator/IC.TAX.TOTL.CP.ZS?year_high_desc=true

Yermachenko, V. E. (2015). Prospects for the Application of the Experience of Transformations in China's Tourism Industry in the Domestic Economy. Chernihiv Scientific Journal, Series 1: Economics and Management, No. 1, 25-38. 